(CC BY 4.0) | ISSN 2525-3409 | DOI: http://dx.doi.org/10.33448/rsd-v9i7.5090

\title{
No percurso da expressão gênica: uma proposta pedagógica para o ensino de Biologia
}

On the path of gene expression: a pedagogical proposal for teaching Biology

En el camino de la expresión genética: una propuesta pedagógica para la enseñanza de la Biología

Recebido: 29/05/2020 | Revisado: 29/05/2020 | Aceito: 03/06/2020 | Publicado: 16/06/2020

\author{
Aliciane de Almeida Roque \\ ORCID: https://orcid.org/0000-0003-4358-1928 \\ Universidade Federal do Paraná, Brasil \\ E-mail: alicianeroque@gmail.com \\ Newton Carlos Will \\ ORCID: https://orcid.org/0000-0003-2976-4533 \\ Universidade Tecnológica Federal do Paraná, Brasil \\ E-mail: will@utfpr.edu.br \\ Lucia Giuliano Caetano \\ ORCID: https://orcid.org/0000-0002-8676-2852 \\ Universidade Estadual de Londrina, Brasil \\ E-mail: luciagiulanocaetano@gmail.com
}

\section{Resumo}

Apesar de uma ciência amplamente presente no cotidiano, grande parte dos estudantes apresentam dificuldades em promover a correlação e visualização das aplicações dos conteúdos abordados na disciplina de Genética molecular. Isto dificulta a construção e consolidação dos saberes que englobam os conteúdos relacionados a esta área do conhecimento, tornando-os abstratos e distantes de sua realidade pessoal. Dentre as alternativas para facilitar o processo de ensino, destaca-se a diversificação de modalidades didáticas, como a realização de aulas práticas, modelos didáticos, aplicação de jogos e recursos audiovisuais, pois contribuem para despertar o interesse e motivação dos estudantes. Assim, em razão das dificuldades recorrentes acerca da aprendizagem do conteúdo de expressão gênica, a proposta pedagógica "No percurso da expressão gênica", foi desenvolvida com intuito de otimizar o processo de ensino-aprendizagem deste conteúdo. Para este feito, o método foi estruturado em duas etapas, sendo na primeira apresentado as sequências dos processos e contemplado importantes conceitos, através de uma estratégia divertida que 
consiste na aplicação de um jogo didático tipo Ludo. Na segunda etapa os estudantes são incentivados a revisar o conteúdo abordado ao longo do primeiro momento e a colaborarem através de discussões e compartilhamento de saberes para que possam solucionar o desafio proposto. O objetivo é apresentar um método de ensino que possa auxiliar na compreensão do processo de expressão gênica, sendo esperado que após a integração desta prática, os conceitos sejam assimilados de forma mais efetiva e palpáveis, especialmente no que concerne aos tópicos sequências e localização subcelular dos produtos gênicos.

Palavras-chave: Transcrição gênica; Tradução proteica; Ensino de Genética molecular; Jogos didáticos.

\section{Abstract}

Despite a science widely present in everyday life, most students have difficulties in promoting the correlation and visualization of the applications of the contents covered in the subject of molecular genetics. This makes it difficult to build and consolidate the knowledge that encompasses the contents related to this area of knowledge, making them abstract and distant from your reality. Among the alternatives to facilitate the teaching process, we highlight the diversification of didactic modalities, such as the realization of practical classes, didactic models, application of games, and audiovisual resources, as they contribute to arouse the interest and motivation of students. Thus, due to the recurring difficulties about learning the content of gene expression, the pedagogical proposal "On the path of gene expression", was developed to optimize the teaching-learning process of this content. For this purpose, the method was structured in two stages, the first one presenting the sequences of the processes and contemplating important concepts, through a fun strategy that consists of the application of a didactic Ludo game. In the second stage, students are encouraged to review the content covered during the first moment and to collaborate through discussions and knowledge sharing so that they can solve the proposed challenge. The objective is to present a teaching method that can assist in understanding the process of gene expression, and it is expected that after the integration of this practice, the concepts will be assimilated more effectively and palpably, especially concerning the topics of sequences and subcellular location of gene products.

Keywords: Genetic transcription; Protein translation; Molecular genetics teaching; Educational games. 


\section{Resumen}

A pesar de una ciencia ampliamente presente en la vida cotidiana, la mayoría de los estudiantes tienen dificultades para promover la correlación y visualización de las aplicaciones de los contenidos cubiertos en la disciplina de la genética molecular. Esto dificulta la construcción y consolidación del conocimiento que abarca los contenidos relacionados con esta área de conocimiento, haciéndolos abstractos y distantes de su realidad personal. Entre las alternativas para facilitar el proceso de enseñanza, destacamos la diversificación de modalidades didácticas, como la realización de clases prácticas, modelos didácticos, aplicación de juegos y recursos audiovisuales, ya que contribuyen a despertar el interés y la motivación de los alumnos. Así, debido a las dificultades recurrentes sobre el aprendizaje del contenido de la expresión génica, se desarrolló la propuesta pedagógica "En el camino de la expresión génica", para optimizar el proceso de enseñanza-aprendizaje de este contenido. Para ello, el método se estructuró en dos etapas, la primera presentando las secuencias de los procesos y contemplando conceptos importantes, a través de una divertida estrategia que consiste en la aplicación de un juego didáctico tipo Ludo. En la segunda etapa, se alienta a los estudiantes a revisar el contenido cubierto durante el primer momento y a colaborar a través de discusiones e intercambio de conocimientos para que puedan resolver el desafío propuesto. El objetivo es presentar un método de enseñanza que pueda ayudar a comprender el proceso de expresión génica, y se espera que después de la integración de esta práctica, los conceptos se asimilen de una manera más efectiva y palpable, especialmente con respecto a los temas de secuencias y ubicación subcelular de productos genéticos

Palabras clave: Transcripción genética; Traducción de proteínas; Enseñanza de la genética molecular; Juegos educacionales.

\section{Introdução}

A genética compreende uma ciência relativamente nova, a qual após a redescoberta dos trabalhos de Gregor Mendel, no início do século XX, emergiu como uma promissora área da Biologia moderna (Souza et al., 2013). Nas últimas décadas, os avanços tecnológicos e científicos possibilitaram o aprimoramento do conhecimento sobre o tema Genética molecular, área da Genética que ocupa-se majoritariamente do estudo da estrutura e função dos genes, de modo que isso têm repercutido cada vez mais sobre a vida da população (Carboni \& Soares, 2010; Martinez et al., 2006). Como seu estudo visa desvendar características dos seres vivos e a partir deste conhecimento promover o progresso 
tecnológico das sociedades, consiste numa ciência amplamente presente na vida das pessoas (Cruz da Rocha \& Roxo Sperandio, 2016). Conforme Hepp e Nonohay (2016), o último século foi marcado por importantes acontecimentos, como identificação estrutural e funcional do ácido desoxirribonucleico (DNA), bem como o desenvolvimento e aperfeiçoamento de técnicas moleculares que permitiram o isolamento, manipulação, multiplicação e sequenciamento desta molécula. A ampliação do conhecimento sobre a organização e regulação da expressão gênica dos organismos contribuiu para progressos significativos desde o desenvolvimento de vacinas e novas terapias no campo da saúde até a produção de cultivares transgênicas altamente produtivas para o suprimento da crescente demanda mundial (Faleiro \& Andrade, 2009).

Entretanto, apesar desta onipresença, grande parte do público considera tanto a Genética como a Biologia molecular, disciplinas de difícil compreensão, de modo que as dificuldades de correlação entre os conteúdos abordados em sala de aula ao cotidiano comum, tem motivado frequentes reclamações entre os estudantes (Cruz da Rocha \& Roxo Sperandio, 2016; Oca, 1995). Acredita-se que o cerne destas dificuldades esteja na ausência de visão sobre as aplicações e implicações práticas destes conhecimentos, o que dificultam a construção e consolidação dos saberes que englobam os conteúdos relacionados ao campo da Genética molecular, tornando-os bastante vagos e distantes da realidade dos educandos (Temp \& Bartholomei-Santos, 2013). Conforme os autores supracitados, caso não sejam abordados métodos de ensino diferenciados, torna-se realmente difícil a compreensão de conceitos tão abstratos quanto genes e expressão de proteínas.

De acordo com Sousa et al. (2016) a formação continuada é imprescindível para que os docentes possam contornar esta problemática, uma vez que lhes oportuniza a atualização de seus conhecimentos para que se sintam mais seguros com relação a conteúdos tão dinâmicos como é o caso da Genética molecular, cujos saberes estão diariamente evoluindo e sendo atualizados. Outra vantagem da constante formação continuada é a possibilidade do compartilhamento de experiências e ideias para a elaboração de métodos didáticos direcionados à aproximação da teoria ao contexto de vida do estudante, de modo que ele consiga visualizar suas aplicações práticas.

Porém, o ensino destes conteúdos quando adotado de forma predominante livresca e teórica, além de ser de difícil compreensão pode resultar em consequências indesejáveis, pois, ao invés de conquistar o interesse dos estudantes, o modo complexo como for abordado pode resultar em aversão. Isto fica evidente no trabalho de Carboni e Soares (2010), demonstrando que a Genética é vista como um dos conteúdos mais temidos e difíceis da Biologia. No 
mesmo sentido, uma pesquisa realizada por Saraiva et al. (2016), com estudantes matriculados no ensino médio, apontou que muitos não sabiam responder adequadamente o significado do termo "Genética". Segundo os autores, ao serem solicitados para responder questões relacionadas a este conteúdo, boa parte não conseguia formular respostas coerentes e acabava misturando termos de diversos conceitos, expondo sérias preocupações a respeito da forma como o conteúdo de Genética vem sendo trabalhado.

Fica assim evidente que a maneira como o professor conduz sua aula é decisiva para o sucesso ou declínio no que concerne a compreensão de conteúdos tradicionalmente considerados complexos como é o caso da Genética e Biologia molecular. Para Ventura et al. (2016), a utilização de métodos diversificados para complementar suas aulas teóricas e facilitar o entendimento do conteúdo por parte dos estudantes demonstrou resultados bastante positivos e é algo que merece ser difundido entre os professores. Neste contexto, o emprego de jogos educativos têm sido promissores, uma vez que, a aplicação deste tipo de atividade, além de auxiliar na compreensão e assimilação de conceitos trabalhados, favorece a capacidade de pensar coletivamente e criticamente (Carvalho et al., 2018).

Para Cavalcanti et al. (2013), os jogos educativos são importantes meios educacionais uma vez que propiciam o desenvolvimento de habilidades cognitivas estimulando diferentes áreas como afetiva, linguística, social, moral e motora, além de contribuir para a construção da autonomia, criatividade e colaboração entre os participantes. Assim, o jogo ganha espaço como ferramenta educativa, uma vez que é capaz de estimular o interesse do educando e preencher possíveis lacunas existentes após a explanação teórica, tornando-se, portanto, uma excelente alternativa para melhorar o desempenho de estudantes quando se trata de conteúdos de difícil aprendizagem (Rocha \& Rodrigues, 2018).

Deste modo, considerando a real dificuldade que os alunos demonstram acerca do processo de expressão gênica e, qual é a influência que esse importante processo desempenha para o funcionamento dos organismos, optou-se pelo desenvolvimento de uma proposta pedagógica a fim de otimizar o processo de ensino-aprendizagem deste conteúdo, de modo que esta ferramenta possa auxiliar na consolidação deste conhecimento. Esta proposta pedagógica foi estruturada em duas etapas e destina-se ao trabalho com estudantes do Ensino Médio, englobando a explicação de importantes conceitos relacionados ao conteúdo de expressão gênica, bem como a descrição de suas principais etapas.

O objetivo é apresentar um método de ensino que possa auxiliar na compreensão do processo de expressão gênica, sendo esperado que após a integração desta prática em sala de aula, os conceitos sejam assimilados pelos envolvidos de forma mais efetiva e palpáveis, 
especialmente no que concerne aos tópicos sequências e localização subcelular dos produtos gênicos.

\section{Metodologia}

$\mathrm{Na}$ literatura, são amplamente destacados os benefícios da inclusão de recursos didáticos diferenciados como facilitadores do processo de ensino-aprendizagem (Carvalho et al., 2018; Cruz da Rocha \& Roxo Sperandio, 2016; Jann \& Leite, 2010). Neste sentido, a confecção desta proposta pedagógica, além de levar em consideração o descrito sobre jogos educativos e ludicidade, exigiu também a pesquisa específica sobre os conteúdos de Biologia Molecular e Genética em material atualizado e de alta confiabilidade (Alberts et al., 2011, 2017; Nelson \& Cox, 2014; Robinson, 2015; Watson, 2014). Após, com base na consulta em livros didáticos (Amabis \& Martho, 2010; Bröckelmann, 2013; Linhares \& Gewandsznajder, 2010) e sites da área de ensino, realizou-se a adequação do grau de complexidade do assunto ao nível escolar a ser trabalhado, no caso $3^{\circ}$ ano do ensino médio.

Intitulada "No percurso da expressão gênica: uma proposta pedagógica para o ensino de Biologia", o método está estruturado em duas etapas. Na primeira elaborou-se um jogo de tabuleiro tipo Ludo, mas com adequações para atender o conteúdo de expressão gênica, mais precisamente a contemplada por organismos eucariontes, consideravelmente mais complexa do que a de seres procariontes. Nesta etapa os estudantes são familiarizados com importantes conceitos que possibilitam o aprendizado/revisão sobre os principais processos compreendidos pela expressão gênica em células eucarióticas, com destaque para informações sobre os locais de acontecimentos, organelas envolvidas e produtos gerados. Além disso, esta etapa está enriquecida com uma série de informações sobre os principais acontecimentos e descobertas científicas que permitiram desvendar os mistérios deste fascinante processo biológico. Espera-se que a partir das informações disponibilizadas ao longo da participação ativa neste jogo, as quais devem ser enriquecidas pelas discussões propiciadas pelo trabalho em grupo, os participantes possam realizar a segunda etapa que consiste na resolução de um desafio relacionado ao conteúdo previamente abordado.

Para que sejam bem sucedidos, a segunda etapa exige que os estudantes sumarizem e reflitam sobre o conteúdo abordado ao longo da primeira etapa. Para isso, é aconselhável que os participantes revisem as informações disponibilizadas durante a etapa anterior e incentivado a realização de discussões de modo a favorecer a construção do conhecimento e aprendizado de forma colaborativa. 


\section{Materiais e dinâmica da atividade}

\subsection{Materiais}

Para aplicação desta proposta são requeridos os seguintes materiais:

$\checkmark \quad 1$ Tabuleiro de jogo (Figura 1);

$\checkmark$ Fichas das personalidades científicas (Figura 2);

$\checkmark 48$ cartas, sendo 16 informação, 20 questão e 12 surpresa (Figura 3);

$\checkmark$ Peão e dado (Figura 4);

$\checkmark$ Determinações da casa conforme símbolo especificado (Quadro 1)

$\checkmark$ Modelos didáticos (Figura 5).

$\checkmark$ Desafio (Quadro 2);

$\checkmark$ Código genético (Figura 6);

$\checkmark$ Dicas para realização do desafio (Quadro 3);

$\checkmark$ Gabarito desafio (Quadro 4).

\subsection{Dinâmica do jogo: Ludo da expressão gênica}

Neste jogo, os alunos podem ser distribuídos das seguintes maneiras: 1- grupos de quatro por tabuleiro, para partidas individuais; 2- grupos de oito para partidas em dupla. A definição do tamanho dos grupos deve ficar a cargo do professor, considerando as peculiaridades de cada turma, entretanto recomenda-se a opção de partidas em duplas sempre que possível, uma vez que permite maior integração e socialização do conhecimento entre os participantes.

Após a divisão dos grupos, deve-se realizar a distribuição dos tabuleiros para que os alunos possam melhor acompanhar as instruções acerca dos procedimentos durante a atividade (Figura 1). 
Figura 1 - Tabuleiro: Ludo da expressão gênica.

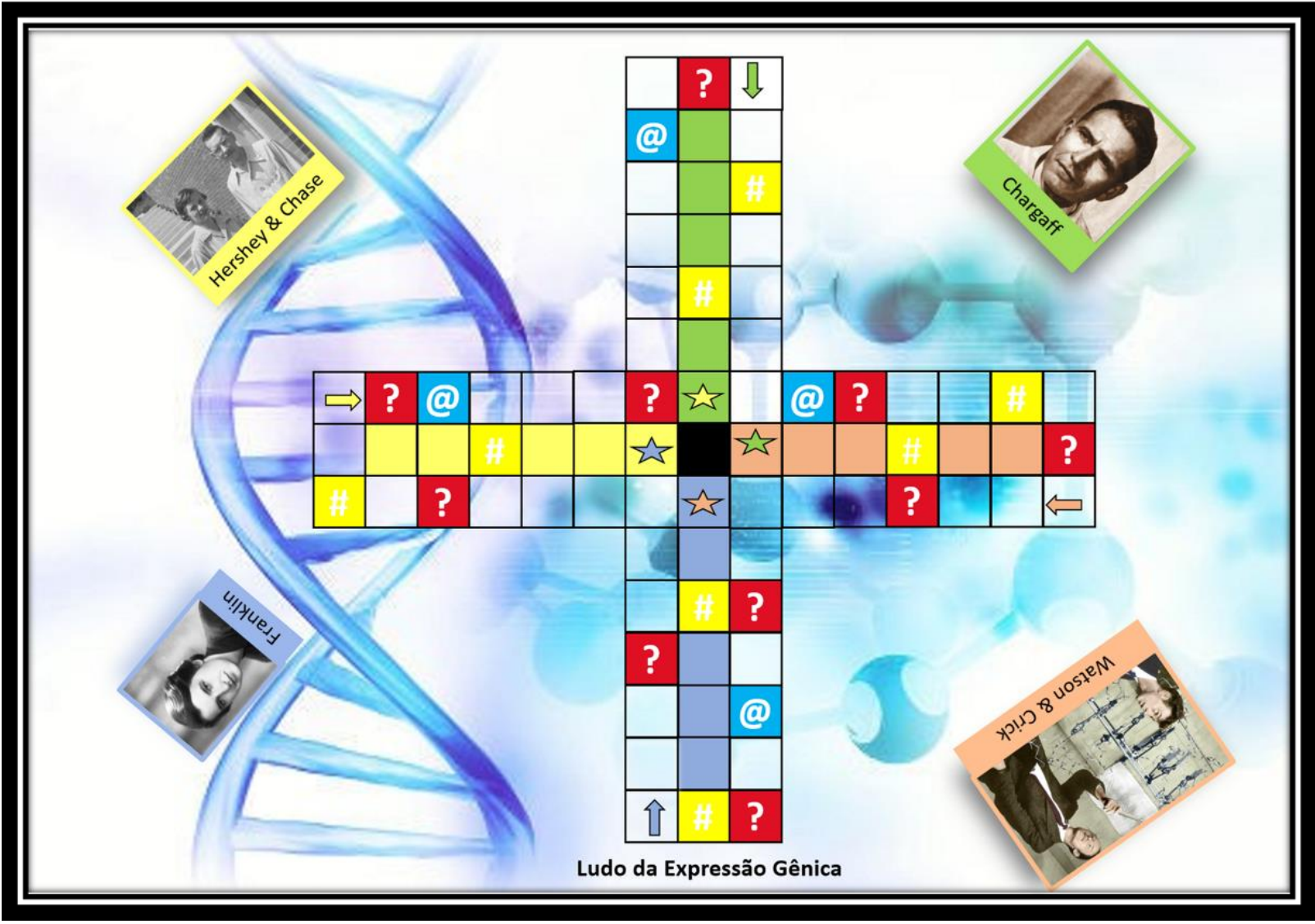

Fonte: elaborado pelos autores.

Note que cada jogador/dupla será representado por uma personalidade científica correspondente a um peão de cor diferente. Para auxiliá-los na decisão de qual personalidade representar, deve ser apresentado o breve relato acerca de suas contribuições científicas (Figura 2).

Antes do início da partida, os jogadores/dupla devem fazer o lançamento do dado para a definição da ordem das jogadas. Os peões partem dos seus respectivos inícios, apontados por setas de diferentes cores conforme a personalidade científica representada e percorrem todo tabuleiro, avançando ou regredindo conforme o número de casas estabelecido pelo dado e cartas (Figura 3). 
Figura 2 - Personalidades científicas.

\section{Alfred Hershey e Martha Chase}

A partir de seus experimentos laboratoriais, em 1952, demonstraram definitivam ente que os genes são feitos de DNA.

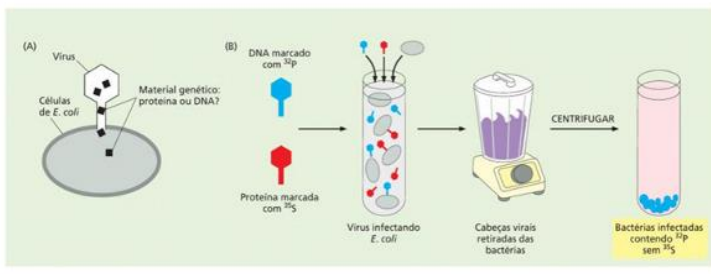

A- Os pesquisadores trabalharam com o virus $\mathrm{T} 2$, o qual é constituido por proteina e DNA.

B- Para determinar se o material genético do vírus era a proteína ou DNA, os pesquisadores marcaram radioativamente o DNA de um lote de virus com ${ }^{32} \mathrm{P}$ e as proteínas de um outro lote de vírus com ${ }^{35} \mathrm{~S}$. Esses vírus marcados foram usados para infectar Escherichia coli, e a mistura foi rompida em um liquidificador para separar a bactéria infectada das cápsulas virais vazias. Ao medir a radioatividade, foi verificado que a maioria do DNA marcado com ${ }^{32} \mathrm{P}$ havia penetrado nas células bacterianas, ao passo que a maioria das proteínas marcadas com ${ }^{35} \mathrm{~S}$ permanecia em solução com o restante das partículas virais.

Fonte: Alberts et al. (2011).

\section{Rosalind Franklin}

Para melhor esclarecer sobre a estrutura do DNA, Franklin e seu colega Maurice Wilkins usaram o método de difração por Raios $\mathrm{X}$ para analisar fibras de DNA.

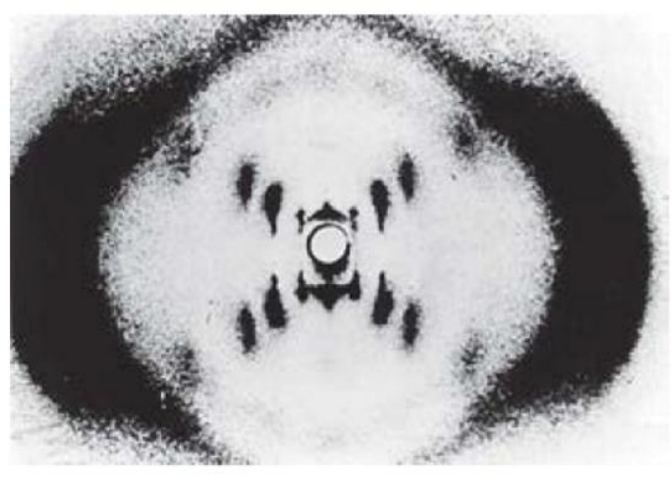

No início dos anos 1950, eles demonstraram que o DNA produz um padrão de difração por raio X característico. A partir desse padrão deduziu-se que as moléculas de DNA são helicoidais. O problema então era propor um modelo tridimensional para a molécula de DNA que fosse compativel não apenas com os dados de difração de raio $\mathrm{X}$, mas também com a equivalência de bases $\mathrm{A}=\mathrm{T}$ e C= $\mathrm{G}$ descoberta por Chargaff e com as outras propriedades químicas do DNA.

Fonte: Nelson e Cox (2014)

Fonte: elaborado pelos autores.

\section{Erwin Chargaff}

E seus colaboradores, descobriram ao final dos anos 1940, que as quatro bases nucleotídicas do DNA eram encontradas em proporções diferentes nos DNAs de organismos de diferentes espécies e que as quantidades de certas bases estavam relacionadas.

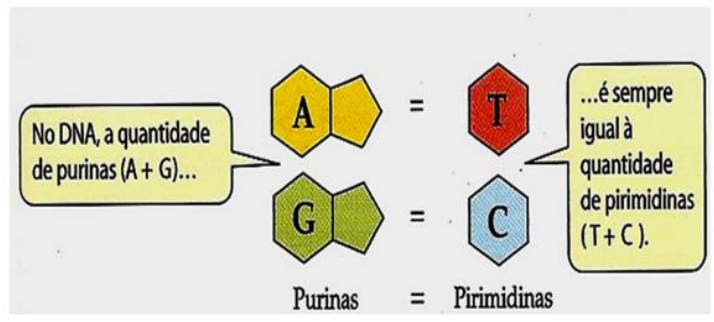

Essas relações quantitativas denominadas "regras de Chargaff", foram confirmadas por muitos outros pesquisadores. Além disso, foram a chave para o estabelecimento da estrutura tridimensional do DNA por Watson e Crick, e também para levantar pistas da forma como a informação genética está codificada no DNA e é transmitida de geração em geração.

Fonte: Nelson e Cox (2014).

\section{James Watson e Francis Crick}

Em 1953, publicaram o famoso artigo de duas páginas descrevendo o modelo para a estrutura do DNA:

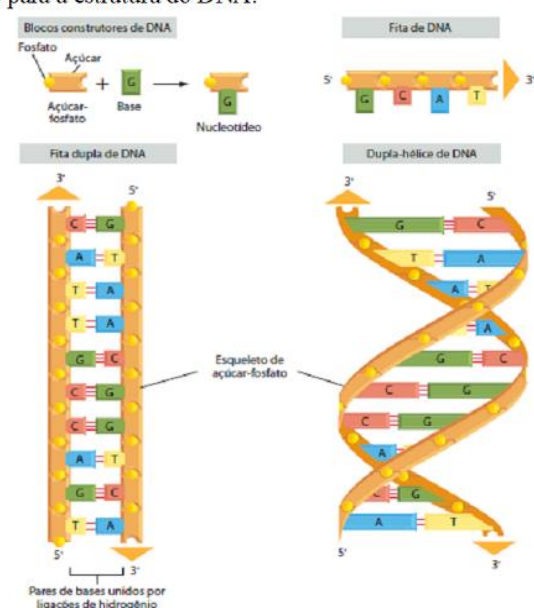

Nesse artigo, eles propuseram que as bases complementares (A-T e G-C) formavam pares entre si, voltadas para o centro de uma dupla-hélice, que mantinha as duas fitas unidas. Os pesquisadores ainda sugeriram um possível mecanismo para a cópia do material genético, onde a dupla-hélice seria desenrolada, e cada fita atuaria como molde para a síntese de uma fita-filha complementar $\rightarrow$ Modelo de Replicação semiconservativa.

Fonte: Alberts et al. (2011) 
Figura 3 - Cartas: Ludo da expressão gênica.

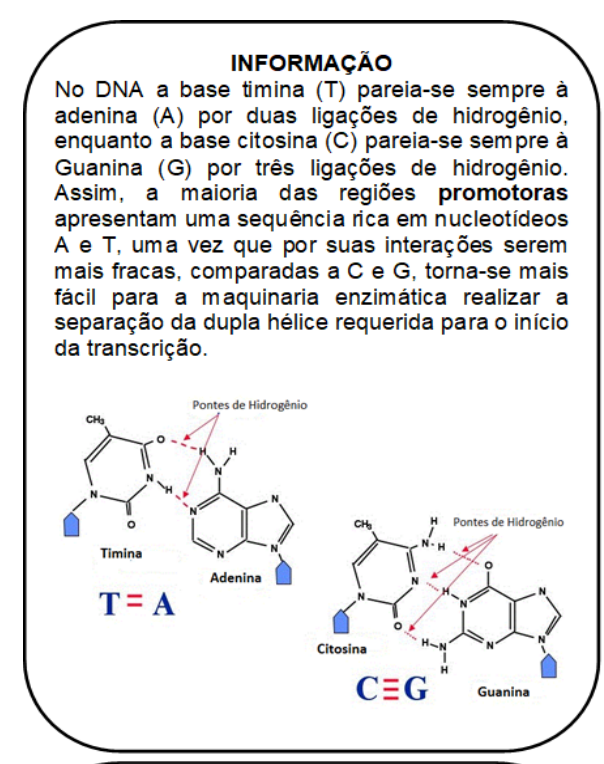

INFORMAÇÃO

INFORMAÇÃO

Processamento do RNA: em eucariotos as sequências codificadoras contidas nos éxons são interrompidas pelos introns. Portanto, para que o RNA transcrito possa ser traduzido, primeiramente devem ser eliminadas as porções correspondentes aos íntrons e realizada união dos éxons adjacentes - splicing. Além disso, para aumentar a estabilidade são adicionadas as suas extremidades, sequências protetoras (início: capeamento -adição de um nucleotídeo guanina; término: poliadenilação -adição de múltiplas adeninas) que aumentam a estabilidade da molécula e informam à célula que aquele transcrito não deve ser degradado.

$$
\text { onu }
$$

() Término

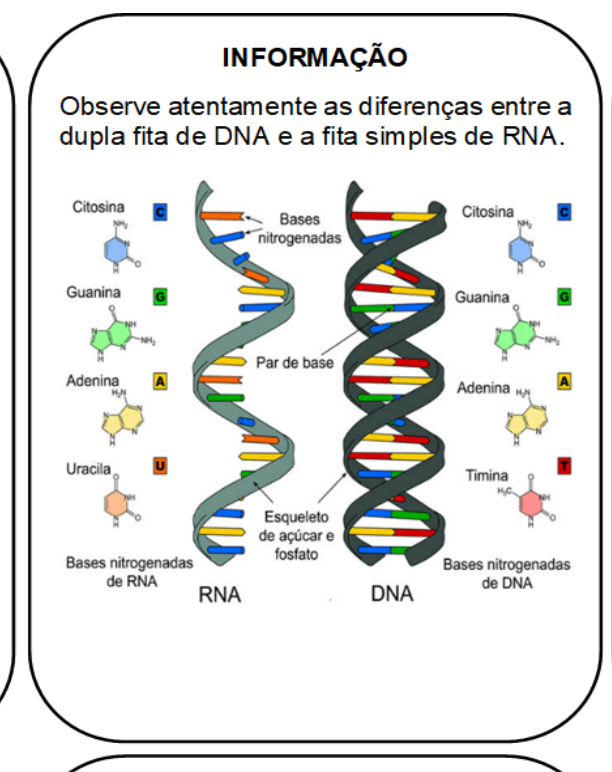

\section{INFORMAÇÃO}

O código genético é chamado de redundante ou degenerado pelo fato de

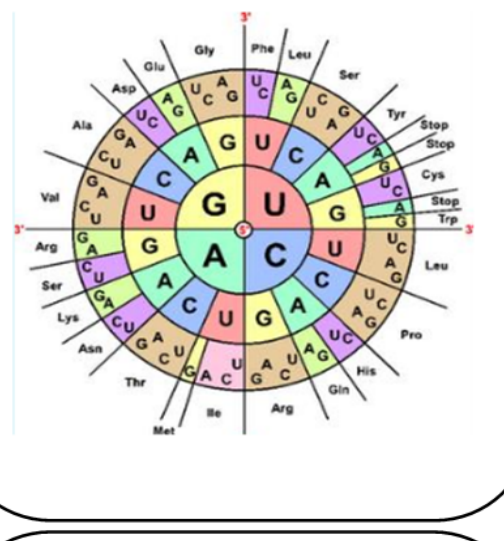

Observe atentamente as etapas da transcrição.

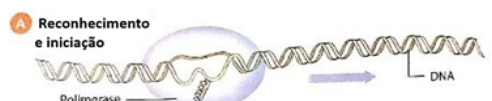

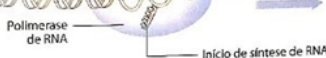

(3) Elongasă

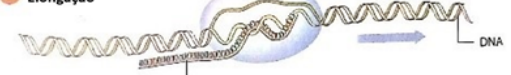

_ Ampliacsio da molkeuia de RNM

$\tau$ - $\begin{gathered}\text { Polimerase } \\ \text { de RNA }\end{gathered}$

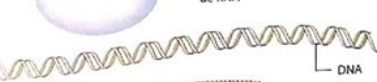
$L_{\text {PNA }}$

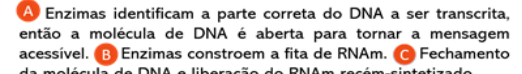

\section{INFORMAÇÃo \\ No citoplasma, cada sequência de três} nucleotidsos do RNAm representa um códon que será finalmente traduzido em um aminoácido. Note que novamente é a propriedade de pareamento dos ácidos nucleicos que permite este fenômeno através dos RNA transportadores (RNAt)

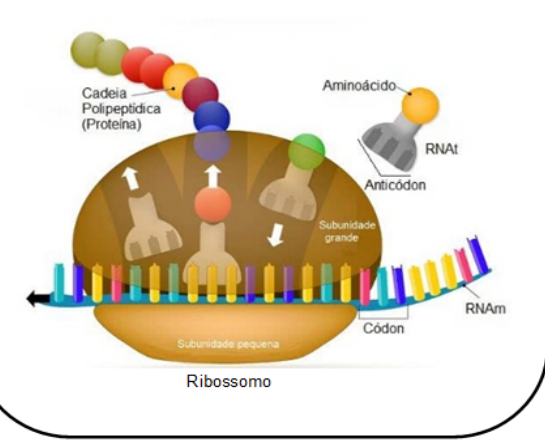

\section{INFORMAÇÃO}

Nos eucariontes os genes são transcritos mo proprio núcleo ao da replicacão. Utilizando uma das fitas a da replicaça. Utizando uma das fitas polimerases de RNA sintetizam cadeias complanentar de paramento de bases similar a que corre na dup hélice de DNA, poré base Timina é substituída pela Uracila.
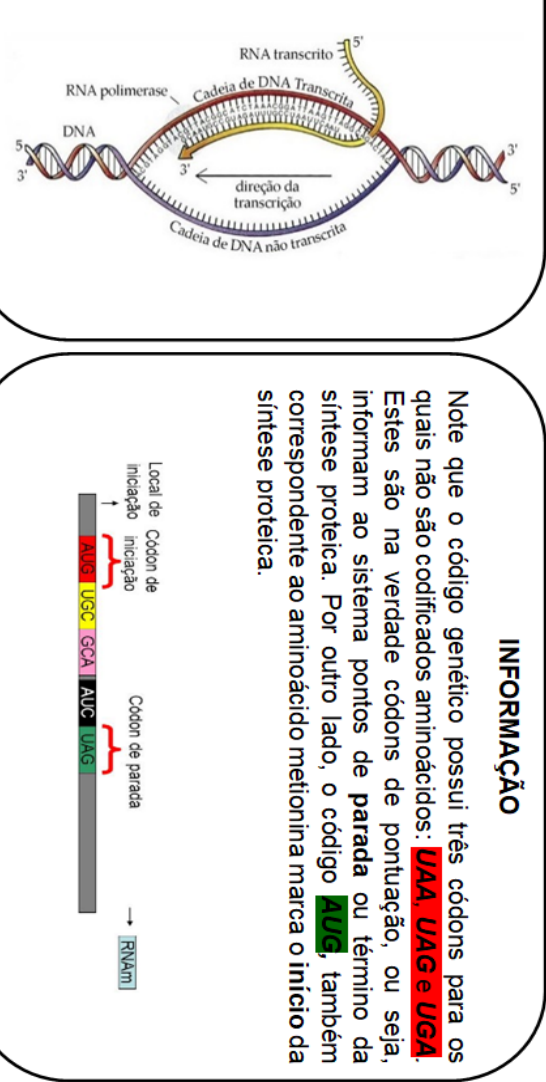
Research, Society and Development, v. 9, n. 7, e906975090, 2020

(CC BY 4.0) | ISSN 2525-3409 | DOI: http://dx.doi.org/10.33448/rsd-v9i7.5090

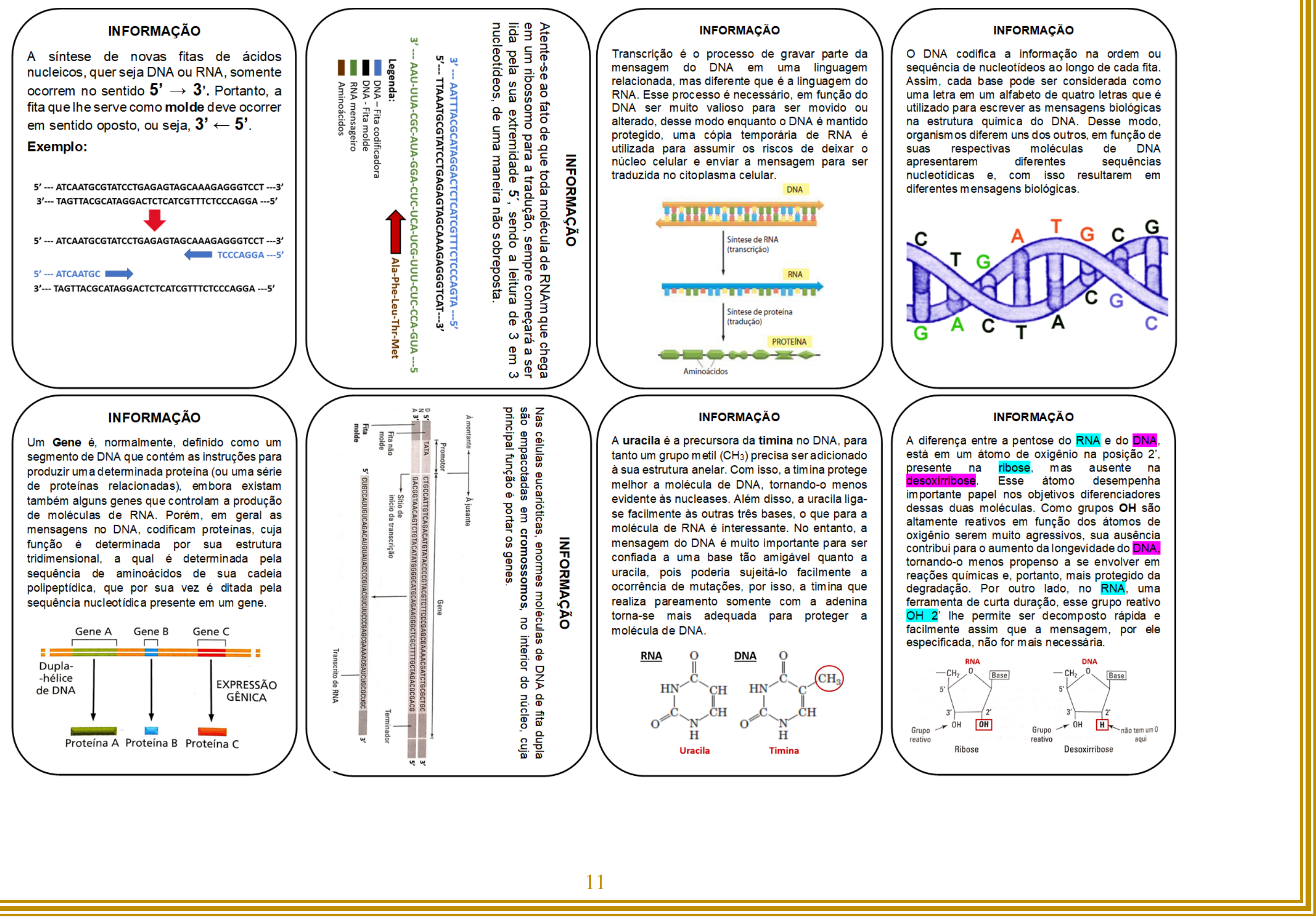


Research, Society and Development, v. 9, n. 7, e906975090, 2020

(CC BY 4.0) | ISSN 2525-3409 | DOI: http://dx.doi.org/10.33448/rsd-v9i7.5090

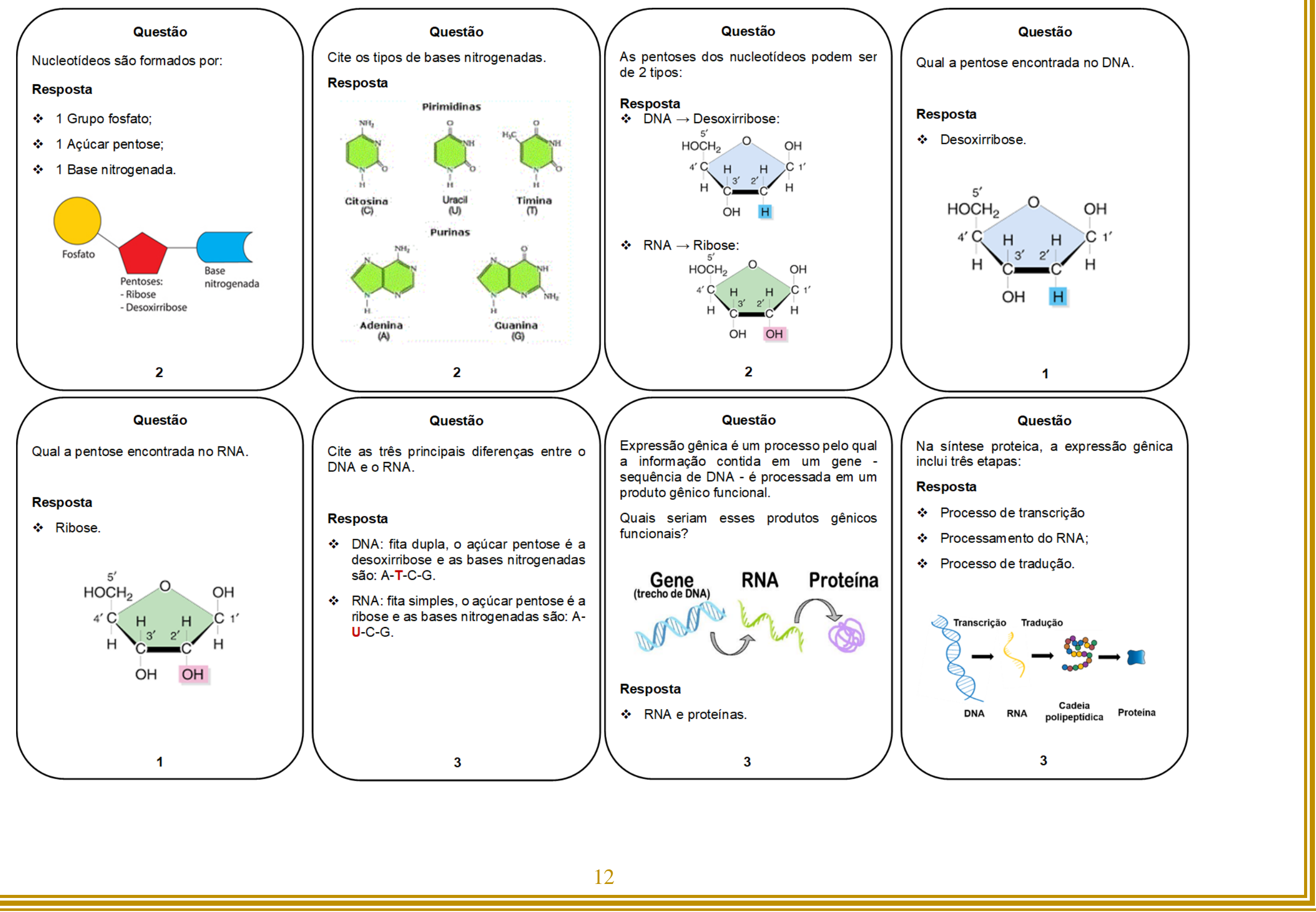


Research, Society and Development, v. 9, n. 7, e906975090, 2020

(CC BY 4.0) | ISSN 2525-3409 | DOI: http://dx.doi.org/10.33448/rsd-v9i7.5090

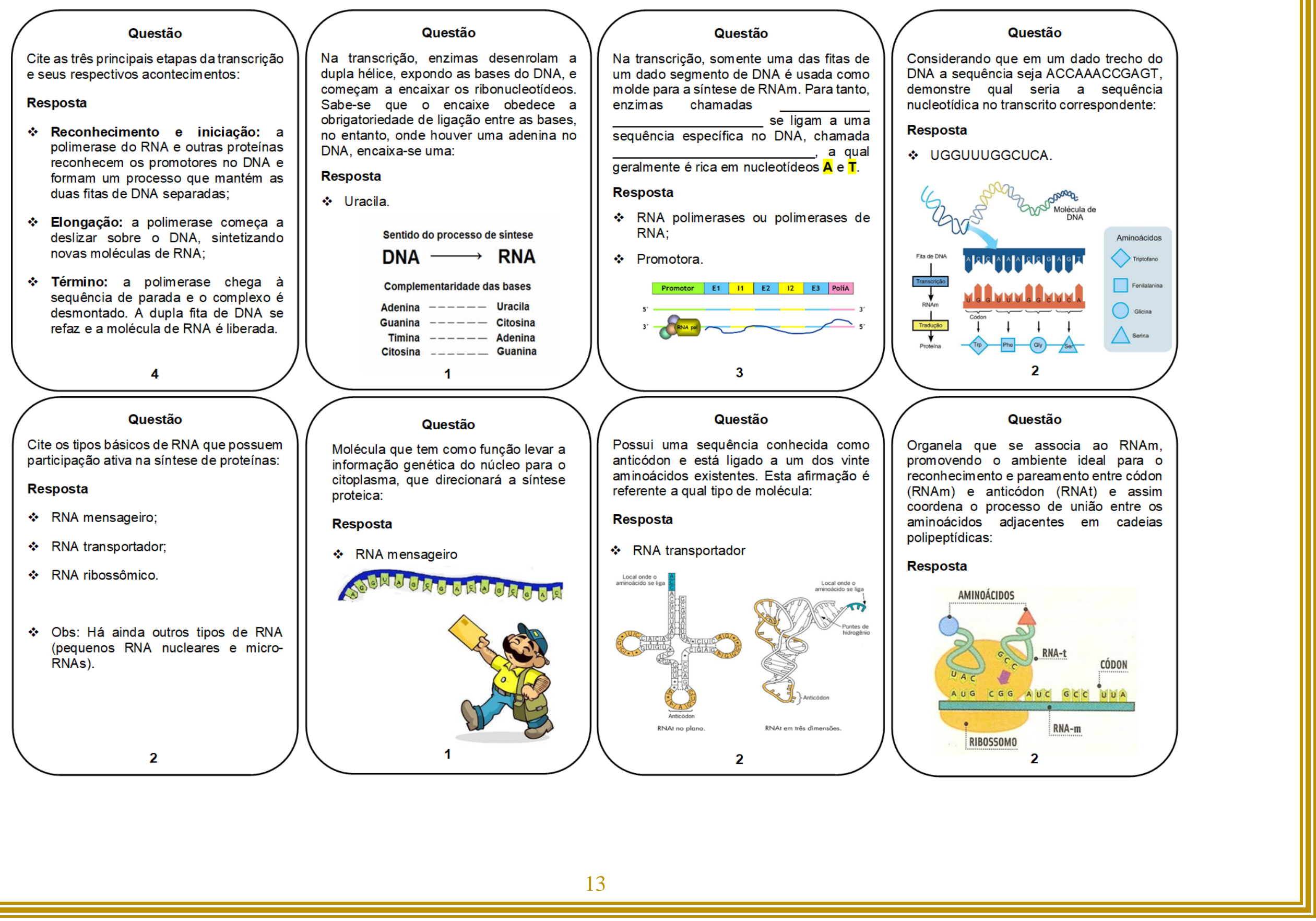


Research, Society and Development, v. 9, n. 7, e906975090, 2020

(CC BY 4.0) | ISSN 2525-3409 | DOI: http://dx.doi.org/10.33448/rsd-v9i7.5090

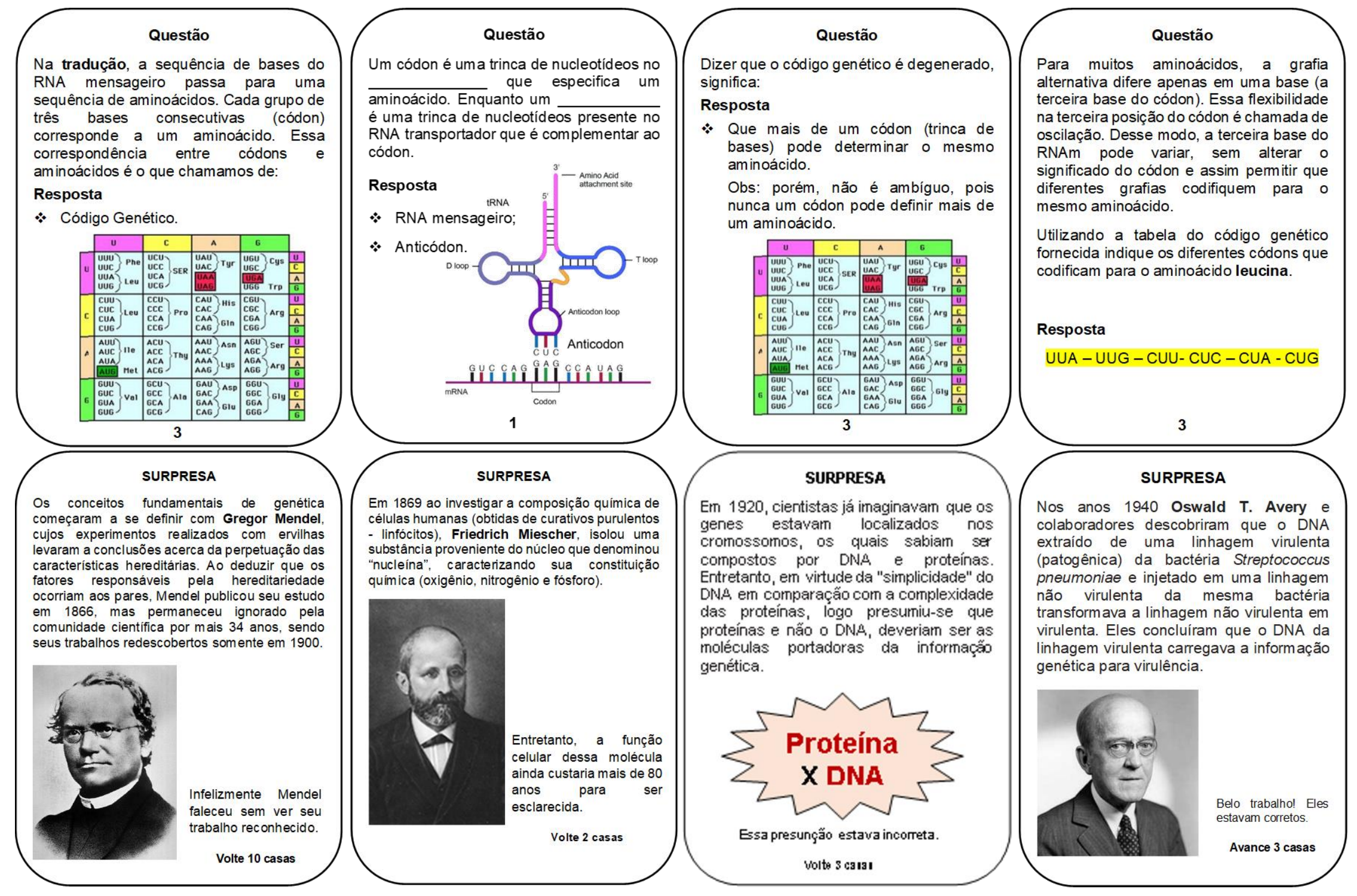


Research, Society and Development, v. 9, n. 7, e906975090, 2020

(CC BY 4.0) | ISSN 2525-3409 | DOI: http://dx.doi.org/10.33448/rsd-v9i7.5090

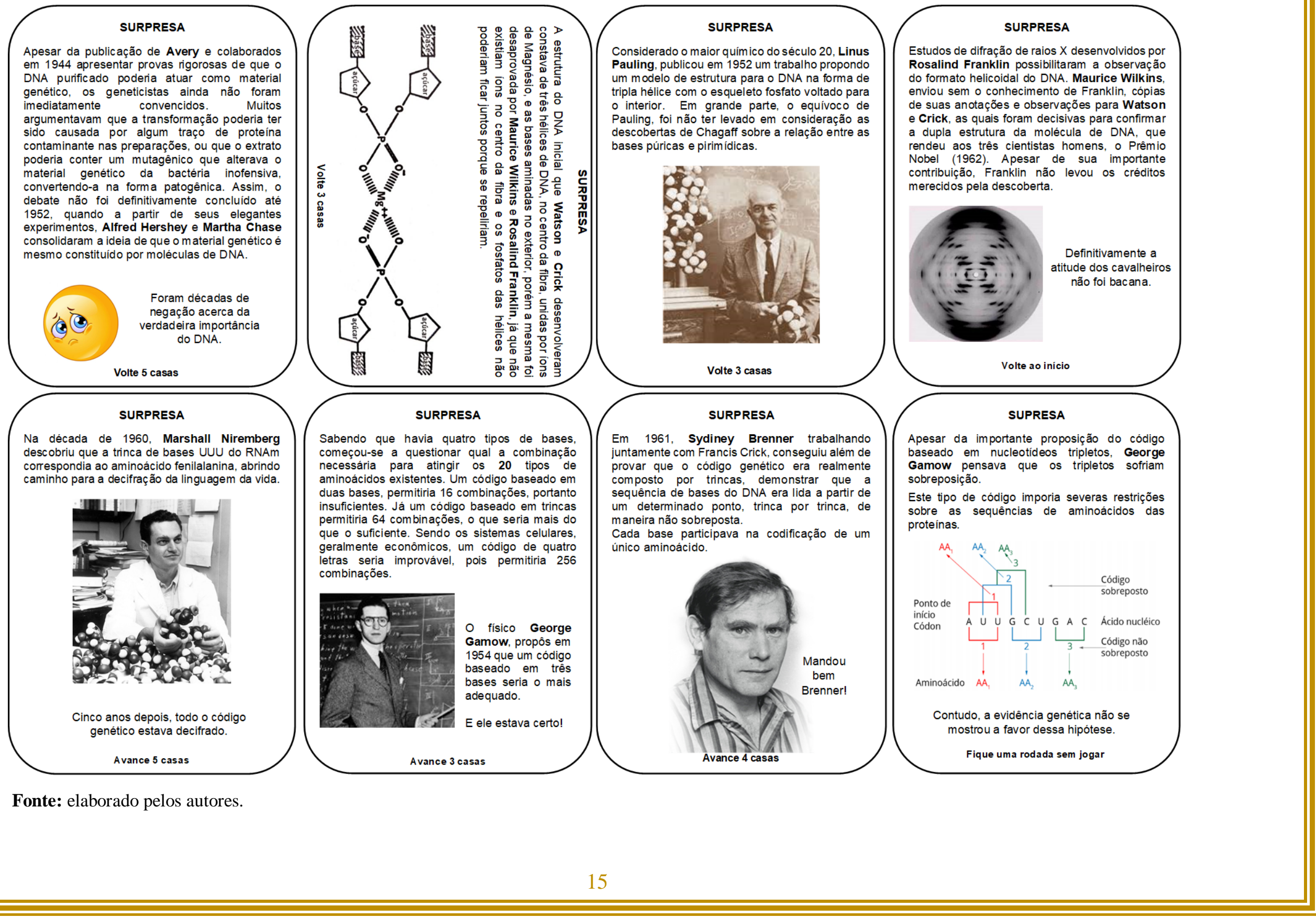


Conhecendo as diferentes realidades escolares, previu-se que em certas situações poderia haver carência de alguns materiais, por isso preocupou-se em disponibilizar para impressão tanto o dado quanto os peões (Figura 4AB). Entretanto o uso desses modelos impressos é apenas uma sugestão, pois caso haja a disponibilidade podem ser utilizados dados próprios e os peões podem ser facilmente substituídos por outros materiais como botões, tampinhas de garrafas ou mesmo por sementes pintadas de diferentes cores.

Figura 4 - A) Dados; B) Peões.

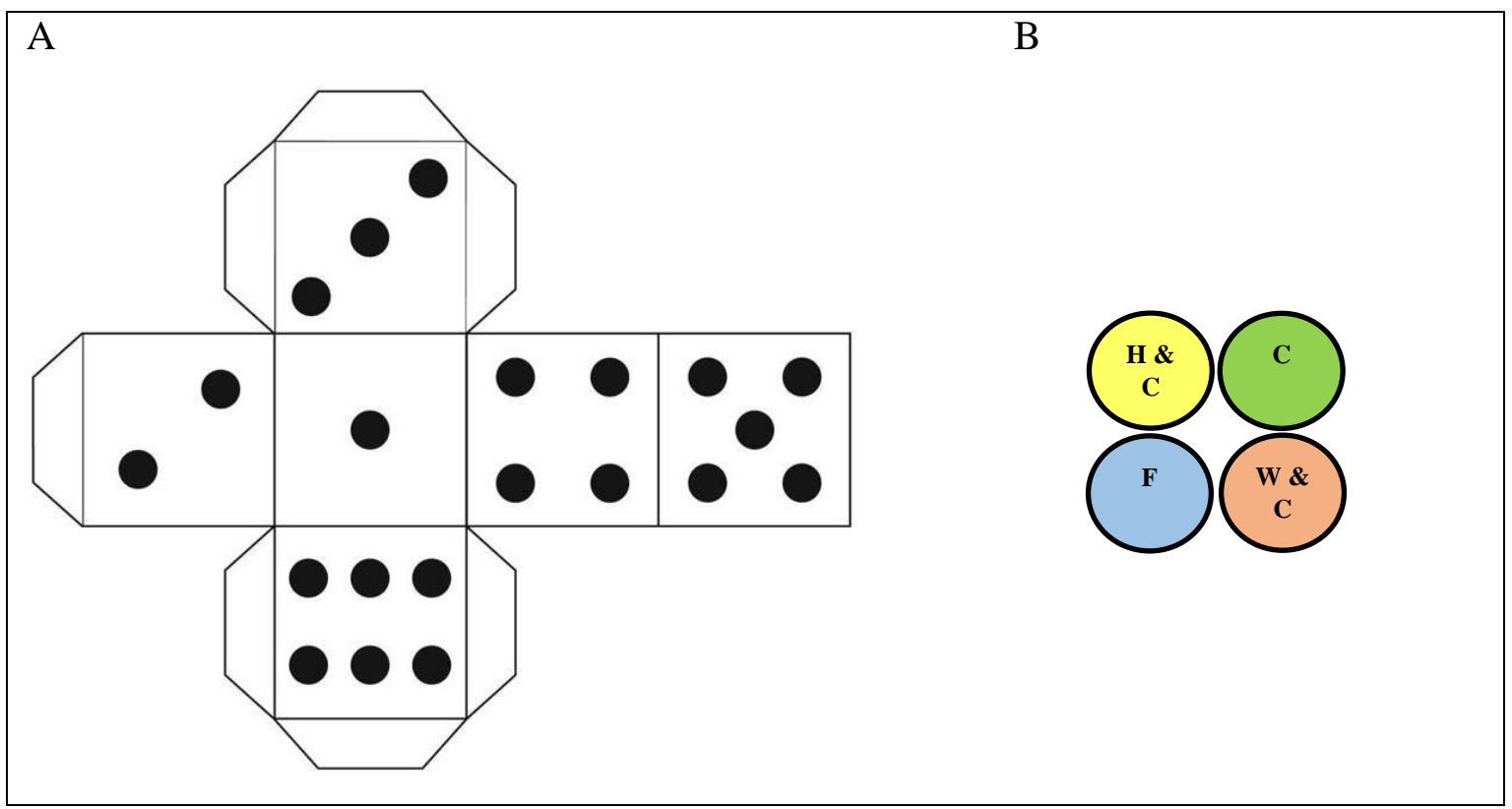

Fonte: elaborado pelos autores.

Cabe salientar que, como a intenção não é substituir a aula teórica, as informações disponibilizadas durante o jogo são mais focadas em destacar detalhes a serem considerados para resolução do desafio do que em responder a questões mais simples, como as solicitadas pelas cartas questões. Embora tais informações também possam ser úteis para esse propósito, recomenda-se que questões mais simples relacionadas ao processo de expressão gênica já tenham sido sanadas pela explicação prévia do professor ou mesmo através do estudo do conteúdo em material didático, uma vez que para o melhor desempenho dos estudantes, a participação nessa atividade requer previamente o conhecimento básico sobre o assunto.

Perceba que em geral, o tabuleiro é composto por casas que permitem a passagem livre, entretanto, ao longo do percurso estão reservados alguns imprevistos, sinalizados por casas com diferentes símbolos conforme descrito no Quadro 1. 
Quadro 1 - Determinações da casa conforme o símbolo especificado.

\begin{tabular}{|c|c|}
\hline @ & $\begin{array}{l}\text { Informação: casa de parada obrigatória } \\
\text { Cada jogador/dupla que por ela passar deve, independentemente do número sorteado } \\
\text { no dado, parar, retirar uma carta do grupo informação e, fazer sua leitura em voz } \\
\text { alta, bem como a demonstração dos elementos figurativos nela impressos para que } \\
\text { todos possam compreender do que se trata. Apesar de não conferir nenhum tipo de } \\
\text { vantagem ou desvantagem no quesito pontuação, estas cartas são de grande } \\
\text { importância, uma vez que os conteúdos nelas descritos visam auxiliar na resolução } \\
\text { das questões propostas ao longo da partida. Por isso, é recomendado que todos } \\
\text { prestem a máximo atenção nessas informações. Considerando que a principal } \\
\text { intenção do jogo é promover a consolidação do conhecimento sobre o conteúdo } \\
\text { expressão gênica, o que vai além da competição individual, o conteúdo presente } \\
\text { nessas cartas deve sempre ser compartilhado e discutido entre todos. }\end{array}$ \\
\hline ? & $\begin{array}{l}\text { Questão } \\
\text { Quando o valor obtido no lançamento do dado determinar que o jogador pare sobre } \\
\text { este tipo de casa, ele precisa responder a uma questão. Para isso, o jogador/dupla que } \\
\text { tiver realizado a jogada anterior deve retirar uma carta do grupo questão e efetuar a } \\
\text { pergunta, dependendo de sua resposta o jogador/dupla poderá avançar ou regressar } \\
\text { conforme o número de casas estabelecidos pela carta. }\end{array}$ \\
\hline \# & $\begin{array}{l}\text { Surpresa } \\
\text { Caso o jogador pare sobre este tipo de casa, deve retirar uma carta deste grupo e } \\
\text { realizar sua leitura em voz alta. De acordo com o conteúdo descrito na carta, o } \\
\text { jogador poderá ser beneficiado ou prejudicado. }\end{array}$ \\
\hline
\end{tabular}

Fonte: elaborado pelos autores.

Vencerá o jogador/dupla que primeiro atingir o ponto central do tabuleiro preenchido pela cor preta, porém os demais participantes devem continuar suas jogadas até o momento em que forem definidas todas as ordens de colocações $\left(1^{\circ}, 2^{\circ}, 3^{\circ}\right.$ e último lugar).

\subsection{Desafio proposto}

Finalizada a realização do jogo, os integrantes do grupo passam a constituir uma só equipe, a qual deve levar em consideração o trecho de DNA a ser transcrito e os recursos didáticos fornecidos na Figura 5 para resolver questões relativas as principais etapas da expressão gênica (Quadro 2). 
Figura 5. Modelos didáticos. A) Dupla fita de DNA; B) Fita simples de RNA sentido 3' -5'; C) Fita simples de RNA sentido 5' - 3'; D) Ribossomo; E) RNA transportador; F) Quepe 5' (capeamento); G) Cauda poli-A (poliadenilação); H) RNA polimerase (direção de leitura $\rightarrow$ ); I) RNA polimerase (direção de leitura $\leftarrow$ ); J) Abreviaturas de aminoácidos; K) Abreviaturas das bases nitrogenadas constituintes do RNA.

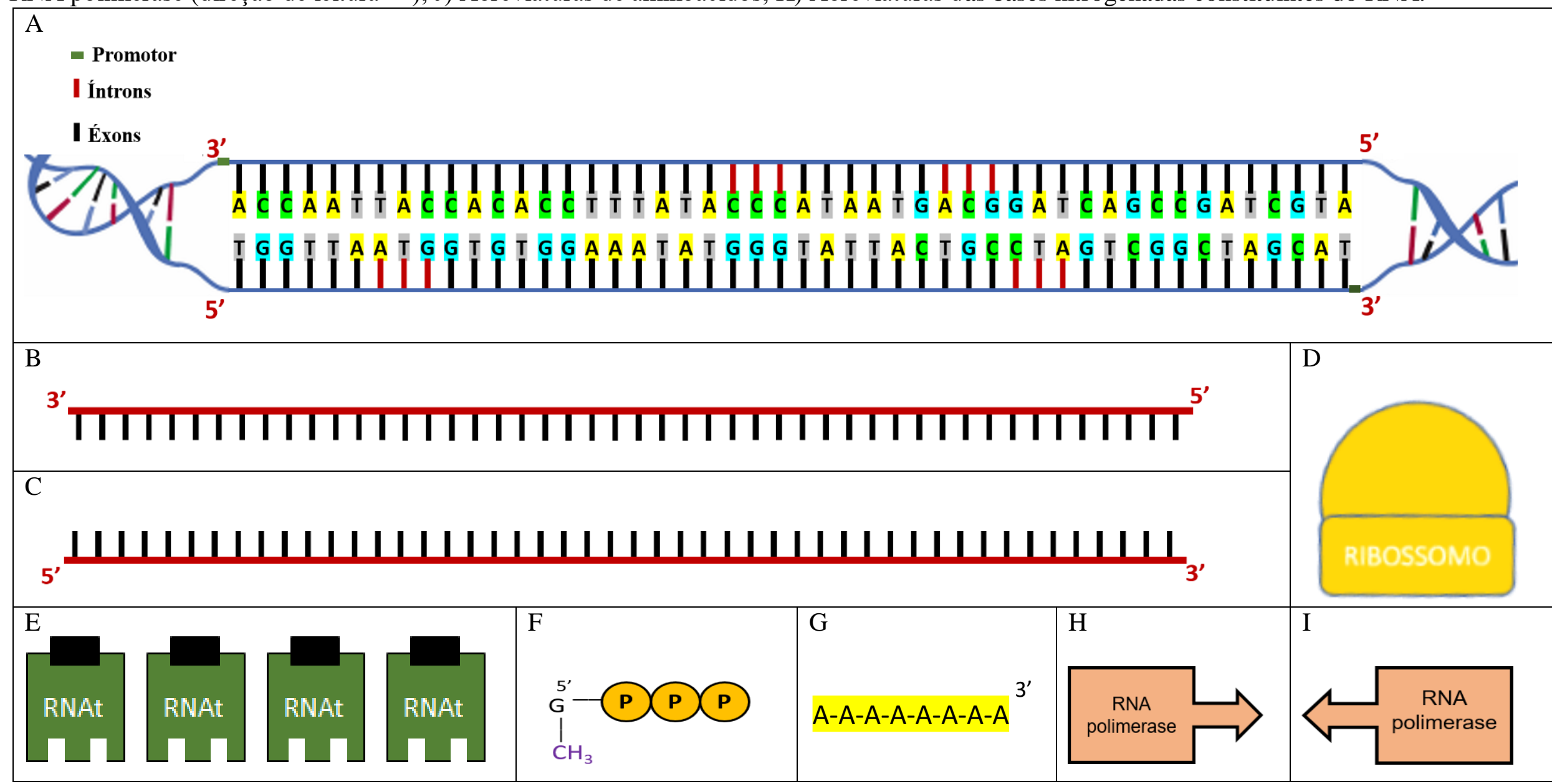




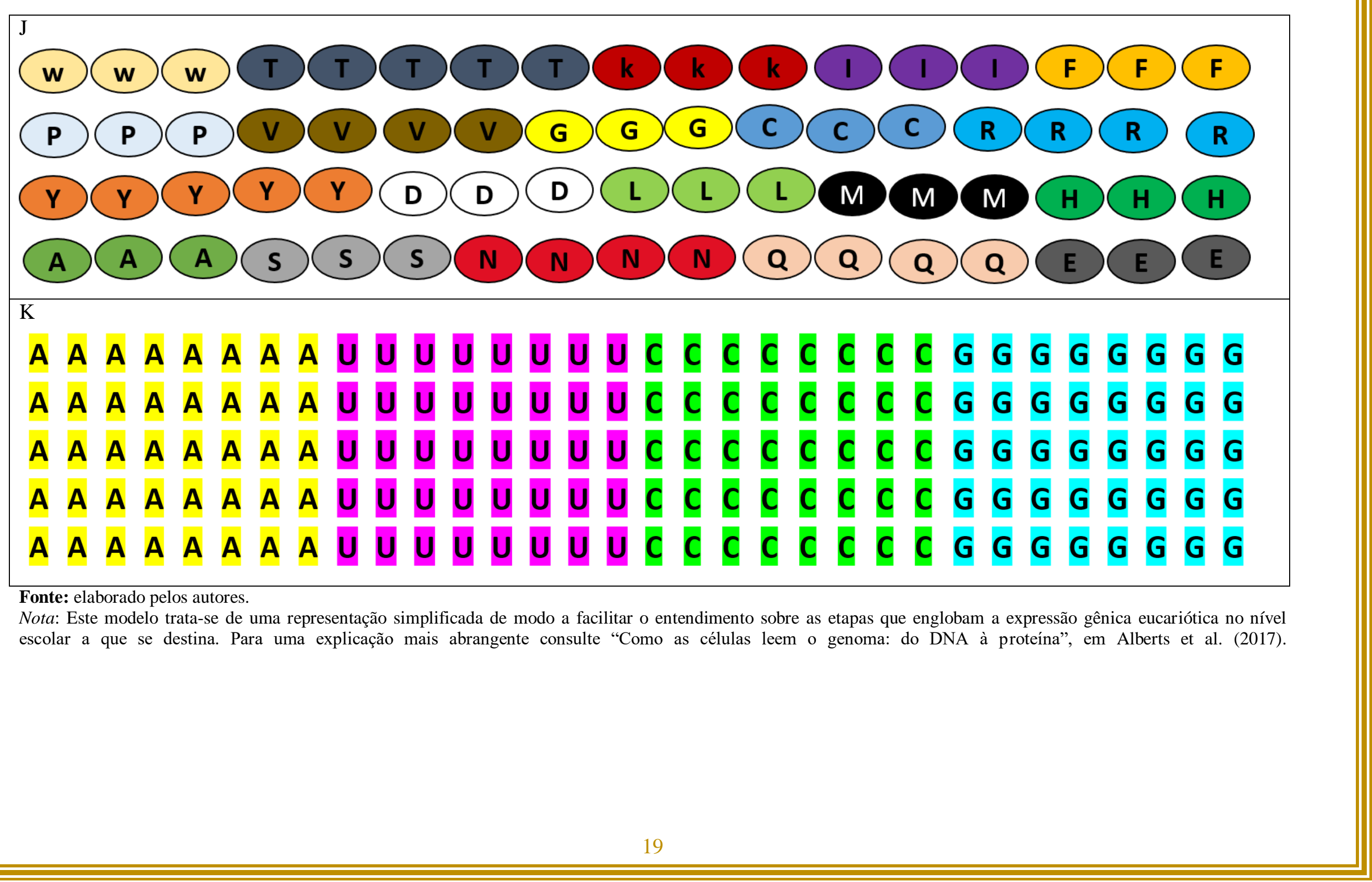


Quadro 2 - Perguntas referentes ao desafio proposto.

1. Sequência de DNA molde.

2. Sequência do transcrito primário.

3. Sequência do transcrito após o processamento.

4. Sequência da cadeia polipeptídica gerada.

5. Sequência de aminoácidos.

6. Não se esqueça de indicar o local de cada evento.

Fonte: elaborado pelos autores.

Para a resolução desta etapa são fornecidos materiais de apoio, dentre os quais a tabela contendo o código genético padrão com uma lista de abreviaturas dos aminoácidos representada na Figura 6.

Figura 6 - Tabela código genético.

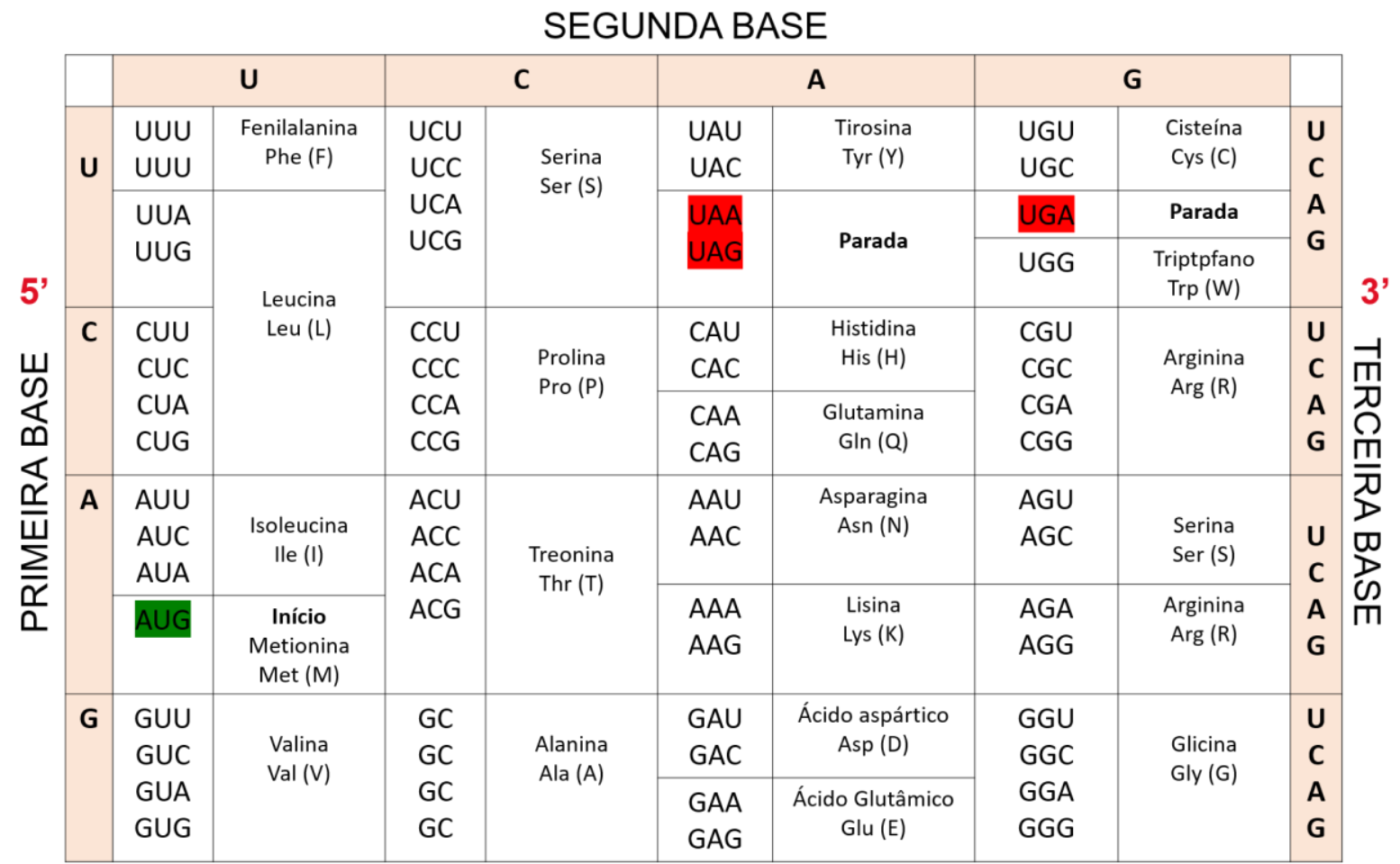

Fonte: elaborado pelos autores.

Note que a tabela referente ao código genético se preocupou em contemplar não apenas os nomes dos aminoácidos referente aos códons designados, mas também suas abreviaturas correspondentes. Estas abreviaturas estão expressas tanto pelo código de três quanto pelo código de apenas uma letra, uma vez que tais informações são de grande utilidade 
para a construção da cadeia polipeptídica a partir dos modelos didáticos previamente apresentados.

A intenção é de que os estudantes construam os transcritos de RNA através da colagem das bases nitrogenadas complementares sobre a fita simples conforme os modelos fornecidos e sigam esta mesma ideia para a montagem da cadeia polipeptídica, apontando ao final os aminoácidos gerados através dos códigos em letras disponibilizados. Portanto, para o melhor aproveitamento e organização da atividade recomenda-se disponibilizar cartolina, pincéis atômicos, tesoura, cola, fita dentre outros materiais que o professor responsável pela aplicação da atividade julgar adequados.

\subsubsection{Dicas para realização do desafio}

No Quadro 3 são apresentadas algumas dicas desenvolvidas com a intenção de auxiliar os estudantes a serem bem sucedidos durante a execução do desafio proposto.

Quadro 3 - Dicas para realização do desafio.

1. Na fita dupla fita de DNA, identifique qual é correspondente a fita molde e qual é a região codificadora;

2. Atente-se para o sentido correto de leitura da sequência de DNA (crescimento da cadeia polinucleotídica): lembre-se que a direção de transcrição é determinada pelo promotor no início de cada gene;

3. Não se esqueça das principais etapas de processamento do RNAm;

4. Atente-se para o sentido correto de leitura da sequência de RNAm (síntese da cadeia peptídica);

5. Em caso de dúvidas consulte as informações disponibilizadas ao longo da primeira etapa da atividade.

Fonte: elaborado pelos autores.

Ao final, o professor deve utilizar o gabarito do desafio apresentado no Quadro 4 para que possam ser realizadas as correções e esclarecimentos de dúvidas sobre a atividade. 
(CC BY 4.0) | ISSN 2525-3409 | DOI: http://dx.doi.org/10.33448/rsd-v9i7.5090

Quadro 4 - Gabarito desafio.

\section{DIREÇÃO DA POLIMERASE $\rightarrow$}

Transcrição e processamento: No interior do núcleo celular

$\checkmark \quad$ DNA molde

3'- ACCAATTACCACACCTTTATACCCATAATGACGGATCAGCCGATCGTA -5 '

$\checkmark \quad$ Transcrito primário

5'-UGGUUAAUGGUGUGGAAAUAUGGGUAUUACUGCCUAGUCGGCUAGCAU -3'

$\checkmark$ Transcrito processado

5'-7MGUGGUUAAUGGUGUGGAAAUAUUAUUACCUAGUCGGCUAGCAUAAAAA-3'

Tradução $\rightarrow$ Nos ribossomos localizados no citoplasma celular:

$\checkmark$ Cadeia polipeptídica

5'- UGG-UUA-AUG-GUG-UGG-AAA-UAU-UAU-UAC-CUA-GUC-GGC-UAG-CAU -3'

$\checkmark$ Aminoácidos

5'- Met - Val - Trp - Lys - Tyr -Tyr - Tyr - Leu - Val - Gly -3'

\section{DIREÇÃO DA POLIMERASE $\leftarrow$}

Transcrição e processamento: No interior do núcleo celular

$\checkmark$ DNA molde

5'-TGGTTAATGGTGTGGAAATATGGGTATTACTGCCTAGTCGGCTAGCAT —3'

$\checkmark \quad$ Transcrito primário

3'- ACCAAUUACCACACCUUUAUACCCAUAAUGACGGAUCAGCCGAUCGUA - 5'

$\checkmark \quad$ Transcrito processado

3'- AAAAAACCAAUCACACCUUUAUACCCAUAAUGACGCAGCCGAUCGUA7MG —5'

Tradução $\rightarrow$ Nos ribossomos localizados no citoplasma celular:

$\checkmark$ Cadeia polipeptídica

5'-AUG-CUA-GCC-GAC-GCA-GUA-AUA-CCC-AUA-UUU-CCA-CAC-UAA-CCA - 3'

$\checkmark$ Aminoácidos

5'- Met - Leu - Ala - Asp - Ala - Val - Ile - Phe - Pro - His - 3'

Fonte: elaborado pelos autores.

A intenção do desafio é fazer com que o conhecimento dos estudantes seja reforçado, de modo que possam revisitar as principais etapas da expressão gênica. Note que no gabarito são evidenciados os processamentos requeridos para que o transcrito primário se torne uma molécula de RNA mensageiro (RNAm) apta a ser exportada do núcleo celular para a tradução nos ribossomos localizados no citoplasma. Estas etapas de processamento englobam o splicing através do qual ocorre a excisão dos íntrons e união das regiões codificadoras compreendidas pelos éxons, além do capeamento (adição de um nucleotídeo guanina 
modificado) e poliadenilação (adição de múltiplos nucleotídeos adenina) ocorridos respectivamente nas extremidades 5' e 3', de modo a garantir a integridade da molécula de RNAm e conferir maior estabilidade e durabilidade, assim evitando a ocorrência de degradação antes do cumprimento de sua função.

Ademais, o desafio intenciona-se fazer com o que o estudante se atente para o sentido correto de transcrição, ocorrido sempre no sentido $5^{\prime} \rightarrow 3^{\prime}$ e, portanto, utilizando como molde a fita de DNA no sentido oposto. Considerando que ambas as fitas de DNA podem servir como molde, destaca-se que a direção da síntese de transcrição realizada pela RNA polimerase depende da localização de regiões promotoras no início de cada gene, o que no modelo está sendo representado pelos traços verdes. Somente RNAm íntegros são direcionados para a tradução nos ribossomos, onde a leitura é realizada de três em três nucleotídeos de maneira não sobreposta, sempre na direção do sentido 5 ' $\rightarrow$ 3'. Também buscou-se representar o papel dos RNA transportadores (RNAt), responsáveis pelo acoplamento dos aminoácidos à cadeia polipeptídica em crescimento, atentando-se para os códons de início (AUG) e parada (UAA, UAG e UGA).

\section{Resultados e Discussão}

A presente proposta resultou em um jogo tipo ludo e na proposição de um desafio, sendo também elaborados materiais didáticos complementares com intuito de apoiar os estudantes durante a resolução das atividades. Para a produção dos recursos gráficos foram empregadas as ferramentas disponíveis no pacote Microsoft Office 2010, como Word, Power Point e Paint. Deste modo evidencia-se a possibilidade para o desenvolvimento de inúmeras atividades a partir de recursos basicamente simples que podem ser facilmente acessados. Em corroboração, Freire et al. (2018) descreve que o emprego de ferramentas digitais para cunho didático contribuí significativamente para o processo de aprendizagem, mas ressalta a necessidade de capacitação do corpo docente para que possam melhor explorar os recursos tecnológicos existentes.

Em função do desenvolvimento de métodos diversificados demandar ampla dedicação e disponibilidade de tempo, sua baixa adesão por parte dos professores do ensino básico pode ser relacionada com o calendário sobrecarregado e ao número reduzido da carga de horaatividade a que estes profissionais estão sujeitos (Temp \& Bartholomei-Santos, 2013). Esta realidade denota que para a melhoria da qualidade do ensino, não só de Genética, mas da educação como um todo, há evidente necessidade de maiores investimentos no setor 
educacional, incluindo melhorias no plano de carreira docente. Conforme Saraiva et al. (2016), o governo deve possibilitar às escolas públicas, o acesso a infraestrutura adequada, com espaços e equipamentos a disposição, além é claro da valorização dos profissionais da educação, bem como a garantia de maior período de hora-atividade para que desta maneira possam melhor elaborar suas aulas.

Ao se pesquisar sobre estratégias de ensino diversificadas, encontram-se muitas possibilidades de intervenções desenvolvidas por alunos de graduação ou pós-graduação, o que na maioria dos casos ocorre para atender exigências em seus respectivos cursos. Deste modo, uma forma de resolver o problema da falta de tempo, seria que os professores fizessem uso dessas estratégias elaboradas por graduandos/pós-graduandos para o enriquecimento de suas aulas. Para tanto, a divulgação destas atividades torna-se imprescindível, já que em muitos casos é possível sua adequação com materiais de baixo custo e, assim promover a aplicação de aulas diferenciadas.

Nesse quesito, a proposta pedagógica aqui descrita merece destaque quanto a facilidade com que permite ser reproduzida. Caso o professor se interesse por sua aplicação, basta que siga as instruções das seções de "Metodologia e Materiais e dinâmica da atividade", onde estão descritas toda as sequências, bem como a impressão dos recursos gráficos elaborados para dar apoio as atividades. A fim de facilitar sua reprodução, foi disponibilizado aos interessados, a descrição resumida dos procedimentos metodológicos bem como todos os recursos gráficos em uma seção de materiais suplementares.

Espera-se que esta ferramenta seja útil tanto para o professor no âmbito didático, quanto para o aluno em compreender melhor os processos de expressão gênica. Recomendase, para seu maior aproveitamento, que a atividade seja aplicada após a abordagem deste conteúdo, como uma maneira de auxiliar no aprofundamento e consolidação do conhecimento. De acordo com Meloni et al. (2018), a aplicação de atividades lúdicas ao cotidiano escolar proporciona inúmeros benefícios, permitindo que o estudante participe ativamente do processo de aprendizagem, além de estimular a socialização, uma vez que incentiva discussões e a construção do trabalho em equipe. $\mathrm{O}$ emprego desta proposta pode também contribuir para o preenchimento de possíveis lacunas, acerca do conteúdo expressão gênica, que tenham sido deixadas durante a explanação teórica. Além disso, se o professor desejar poderá fazer sua aplicação não apenas como forma de revisão e discussão, mas também de modo avaliativo. 


\section{Considerações finais}

Cientes do quão desafiador é para o professor realizar a contextualização dos conteúdos relacionados à Genética molecular de modo a instigar o interesse dos educandos, a proposta pedagógica aqui documentada se emprega de meios lúdicos e foi desenvolvida como forma de auxiliar os professores de Biologia na abordagem do conteúdo expressão gênica.

Ressalta-se que a intenção não é fazer a substituição da aula do professor regente, mas sim que esta ferramenta possa ser utilizada de modo a reforçar o aprendizado e até mesmo para o preenchimento de possíveis lacunas deixadas ao longo da explanação teórica. $\mathrm{O}$ emprego de recursos complementares torna-se fundamental para que a aprendizagem em Biologia seja bem sucedida, uma vez que se trata de uma disciplina que exige ampla capacidade de abstração por parte dos estudantes, além de conhecimentos prévios um tanto complexos atrelados a muitos conceitos.

Deste modo a adoção de recursos didáticos diferenciados revela-se uma estratégia facilitadora para a compreensão de fenômenos biológicos e é uma prática que merece ser difundida para o aprimoramento do processo de ensino. Neste sentido, a formação continuada torna-se uma importante aliada, uma vez que além de oportunizar aos docentes a constante atualização de seus conhecimentos o que é fundamental em uma áreas tão dinâmicas como é o caso da genética e biologia molecular, viabiliza o compartilhamento de experiências e ideias para a elaboração de instrumentos didáticos direcionados à aproximação da teoria ao contexto de vida do estudante, possibilitando a realização de aulas mais atrativas do que quando abordadas de forma predominantemente teóricas.

\section{Referências}

Alberts, B., Bray, D., Hopkin, K., Johnson, A., Lewis, J., Raff, M., \& Wakter, P. (2011).

Fundamentos da Biologia Celular (3. ed.). Porto Alegre: Artmed.

Alberts, B., Johnson, A., Lewis, J., Morgan, D., Raff, M., Roberts, K., \& Walter, P. (2017).

Biologia Molecular da Célula (6. ed.). Porto Alegre: Artmed.

Amabis, J. M., \& Martho, G. R. (2010). Biologia das populações (3. ed.). São Paulo:

Moderna. 
Araújo dos Santos Freire, C. M., Carneiro de Medeiros, S., Carneiro, J. G., Monteiro Júnior, J. E., \& da Cruz Freire, J. E. (2018). Proposta pedagógica em prática no ensino de bioquímica: Aproveitamento de softwares livres como facilitador do processo de ensino e de aprendizagem. Revista Thema, 15(4), 1442-1455. https://doi.org/10.15536/thema.15.2018.1442-1455.934

Bröckelmann, R. H. (2013). Conexões com a biologia (1. ed.). São Paulo: Moderna.

Carboni, P. B., \& Soares, M. A. M. (2010). A genética molecular no ensino médio. Portal Educacional Do Estado Do Paraná, 20. Retrieved from http://www.gestaoescolar.diaadia.pr.gov.br/arquivos/File/producoes_pde/artigo_patricia_berti celli_carboni.pdf

Carvalho, É., Lopes, S. D. P., Magalhães, M. D. F., Lima, M. R., Brandão, N. C. de A., Silva, R. de A. C., \& Rodriguez, M. B. (2018). O Mistério de Marie Rogêt: um jogo de investigação como ferramenta para a aprendizagem e contextualização da genética. Genética Na Escola, 13(2), 202-2021.

Cavalcanti, K. M. P. D. H., Guimarães, C. C., Barbosa, E. L. C. M., \& Sério, S. S. (2013). Ludo Químico: um jogo educativo para o ensino de química e física. In IX Encontro Nacional de Pesquisa em Educação em Ciências - IX ENPEC (pp. 1-8). Águas de Lindóia, SP. Cruz da Rocha, S., \& Roxo Sperandio, V. M. M. (2016). O Lúdico no Ensino de Genética. Cadernos PDE, 2, 47.

Faleiro, F. G., \& Andrade, S. R. M. (2009). Biotecnoogia, transgênicos e biossegurança. Planaltina: Embrapa Cerrados. Retrieved from www.cpac.embrapa.br/download/1655/t

Hepp, D., \& Nonohay, J. S. (2016). A importância das técnicas e análises de DNA. Scientia Tec: Revista de Educação, Ciência e Tecnologia Do IFRS, 3(2), 114-124.

Jann, P. N., \& Leite, M. D. F. (2010). Jogo do DNA: um instrumento pedagógico para o ensino de ciências e biologia. Ciências e Cognição, 15(1), 282-293.

Linhares, S., \& Gewandsznajder, F. (2010). Biologia hoje (1. ed.). São Paulo: Ática. 
Martinez, M. A. R., Francisco, G., Cabral, L. S., Ruiz, I. R. G., \& Neto, C. F. (2006). Genética molecular aplicada ao câncer cutâneo não melanoma. Advances in Dermatology, 81(5), 405-419.

Meloni, J. S., Spiegel, C. N., \& Gomes, S. A. O. (2018). Biotecnologia em jogo: estratégia lúdica para o ensino médio. Genética na Escola, 13(2), 154-183.

Nelson, D. L., \& Cox, M. M. (2014). Princípios de Bioquímica de Lehninger (6. ed.). Porto Alegre: Artmed.

Oca, I. C. M. de. (1995). Que aportes ofrece la investigaticion mas reciente sobre aprendizaje para fundamentar nuevas estrategias didacticas? Revista Educación1, 19(1), 7-16.

Robinson, T. R. (2015). Genética para leigos (2. ed.). Rio de Janeiro: Alta Books.

Rocha, D. F., \& Rodrigues, M. S. (2018). Jogo didático como facilitador para o ensino de biologia no ensino médio. CIPPUS, 8(2), 8.

Saraiva, V. da C., Araújo, M. dos S., Rodrigues, M. B., Sousa, I. C., \& Cruz, E. R. da. (2016). O ensino de genética no $3^{\circ}$ ano do ensino médio com enfoque na engenharia genética. In III Congresso Nacional de Educação - CONEDU (p. 13). Natal, RN.

Sousa, E. S. de, Nunes Junior, F. H., Cavalcante, C. A. M., \& Holanda, D. de A. S. (2016). A Genética em sala de aula: uma análise das percepções e metodologias empregadas por professores das escolas públicas estaduais de Jaguaribe Ceará. Conexões Ciência e Tecnologia, 10(4), 16-24. https://doi.org/10.21439/conexoes.v10i4.1106

Souza, V. S., Dornelles, R. C., Coimbra Junior, C. E. A., \& Santos, R. V. (2013). História da genética no Brasil: um olhar a partir do Museu da Genética da Universidade Federal do Rio Grande do Sul. História, Ciências, Saúde, 20 (2), 675-694. https://doi.org/10.1590/s010459702013000200018

Temp, D. S., \& Bartholomei-Santos, M. L. (2013). Desenvolvimento e uso de um modelo 
didático para facilitar a correlação genótipo-fenótipo. Revista Electrónica de Investigación En Educación En Ciencias, 8(2), 13-20.

Ventura, J. P., Ramanhole, S. K. de S., \& Moulin, M. M. (2016). A importância do uso de jogos didáticos como método facilitador de aprendizagem. In XX Encontro Latino Americano de Iniciação Científica, XVI Encontro Latino Americano de Pós-Graduação e VI Encontro de Iniciação à Docência - (p. 1-5).

Watson, J. D. (2014). A dupla hélice (1. ed.). Rio de Janeiro: Zahar.

\section{Porcentagem de contribuição de cada autor no manuscrito}

Aliciane de Almeida Roque - 50\%

Newton Carlos Will - 20\%

Lucia Giuliano Caetano - 30\% 